\title{
Studies on the Beginnings of the Bronze Age in South-Eastern Poland
}

\author{
Halina Taras ${ }^{a}$
}

\begin{abstract}
The article refers to Jan Kowalczyk's interest in the transition from the Neolithic to the Early Bronze Age in Poland, as well as observations regarding the technological and morphological features of ceramics in the context of his research in Gródek, Hrubieszów district.
\end{abstract}

KEY-WORDS: taxonomy, Corded Ware culture, Mierzanowice culture, Strzyżów culture, Jan Kowalczyk.

The issue of the Bronze Age was beyond the mains focus of Jan Kowalczyk's research interests. However, during the excavations in Gródek, Hrubieszów district, conducted in 1954-1957, he excavated four graves (Kowalczyk 1959: I, published - Głosik 1958a; I958b), which in the preliminary report were attributed to the Corded Ware culture (Kowalczyk 1957: 30I). That inferrence was based on the similarity of the ceramic material to vessels previously discovered in Strzyżów, Hrubieszów district (Podkowińska 1936). At that time, about 90 sites related to the Corded Ware culture, that ended the Neolithic period, were known in Central and Eastern Poland. They were usually represented by single artefacts (Nosek 1957: 84-88, 423, map VI). Such a classification was based largely on intuition, which can be explained by the randomness of selection and stylistic incoherence of the artefacts. Various bifacial tools - arrowheads, bifacial points and sickle-shaped knives etc., of various types and varieties, were assigned to this culture, but much later some of them (e.g. Nosek 1957, table XVIII, XIX) were correctly assigned to cultural units dated to the beginnings of the Bronze Age (Libera 200I: Fig. 37), others (e.g. Nosek 1957: Fig. 30) even to the later phases of this period (Libera 20or: Fig. 39). This also applies to some of the ceramics, arbitrarily related to the Globular Amphora culture, Corded Ware culture or Mierzanowice (vel. Tomaszów) culture, (e.g. Nosek 1957: Fig. 27-29, Table XIII: I, XX: 5, 6). This practice clearly reveals that the state of knowledge about the end of the Neolithic, and the situation at the beginning of the Bronze Age, was very unsatisfactory. From the perspective of cultural taxonomy as it is currently understood, the material thought at that time to

a Institute of Archaeology, Maria Curie-Skłodowska University in Lublin, 4 M. C.-Skłodowska sq., 20-03I Lublin, Poland, e-mail: halina.taras@poczta.umcs.lublin.pl ORCID: o000-0002-8I43-0090 
${ }_{178} \mid$ Halina Taras

represent the Corded Ware culture went beyond the framework of the late Neolithic, extending into the early phases of the Bronze Age.

When J. Kowalczyk classified the grave inventories from Gródek (Kowalczyk 1957), the results of excavations in Strzyżów, where a significant assemblage of material relating to the Early Bronze Age had been excavated, had not yet been published, but only signalled in a interim publication (Podkowińska 1936). However, it was widely believed that this was a Neolithic assemblage. In the first post-war syntheses of the prehistory of Poland, de facto reflecting the state of research from the late I930s (Kostrzewski 1939-I948: map 6), the map of Early Bronze Age settlement in this part of the country is a blank area. On the other hand, it was thought that the Corded Ware culture still existed here (Kostrzewski 1949: map I). Stefan Nosek (1957: 92-94, 424, map VII), however, singled out the sites of Mierzanowice (Tomaszów) culture in the Lublin region, in which he, incorrectly, included, for example, the cemeteries in Skomorochy Małe, Zamość district, and Raciborowice, Chełm district. The cultural individuality of the Strzyżów complexes had not yet been recognised at that time. The separation of the Strzyżów culture took place at the end of the 1950s (Gardawski 1959), and the first monograph, written by Jerzy Głosik, appeared only in 1968.

Jan Kowalczyk, searching for similarities to the materials from Gródek, examined whether the material from the graves could be assigned to the Neolithic Corded Ware culture or the Early Bronze Age Mierzanowice culture (Kowalczyk 1959: 2). Investigating this problem, he compared the "Neolithic Corded Ware" materials from Strzyżów with artefacts from Raciborowice, related to the Mierzanowice culture. This showed that the two groups of material were very similar to each other. Parallel to these findings, Jerzy Głosik (1958a) came to similar conclusions. Then J. Kowalczyk made an attempt to compare this material to the burial ceramics from Mierzanowice. It turned out, however, that the site is culturally heterogeneous - because burials of both the Neolithic Corded Ware culture and Bronze Age Mierzanowice culture coexisted on that cemetery (Kowalczyk 1959: 3-5). Moreover, at that time, the cemetery in Mierzanowice was known only from the initial publication of Kazimierz Salewicz (1937), more attention was paid to it much later (Machnik 1966; Bąbel I978; 2013; Włodarczak 2006).

J. Kowalczyk conducted comparative studies that allowed him to prove that terms such as "Corded Ware culture" and (especially), "Mierzanowice culture" were ambiguous, therefore they could not be treated as monolithic groups in systematizing the source database. He postulated an acceleration in publication of the source-data from the key burial sites, which would allow the taxonomic and chronological verification of material from the turn of the Neolithic and the Bronze Age. This would result in the redefinition of the conceptual range of cultural units from the beginning of the Bronze Age. 
He also formulated the concept of the existence in the Lublin region of a specific group of ceramics with particular, distinct features, for which the term "Strzyżów group of Corded Ware culture" was fully justified (Kowalczyk 1959: 4). This term had been proposed by J. Głosik (1958a: 164). The distinctiveness of this material was manifested, among other things, in a specific treatment of vessels surface by wiping with the use of a straw "brush".

Another important question, raised by J. Kowalczyk in the article titled: Zagadnienie kultury mierzanowickiej zwanej także tomaszowska [The issue of Mierzanowice culture, also known as Tomaszów culture], is the problem of production and dating of faïence beads (1959: 6-7), in older literature considered as Egyptian imports (e.g. Kozłowski 1928: 28, Kostrzewski 1939-48: 204). He expressed the opinion that the studies, including laboratory analyses, of this type of objects from Poland would allow the establishment of their technological details and - as a result - their origin. Such research, conducted a bit earlier (Clark 1957) for finds from the Balkans and the area of Great Britain, revealed the presence of local European centers of production of the faïence beads. In relation to Polish findings, this postulate was realized only a few years ago and fully confirmed the local production of such jewellery. They were made for specific recipients, using local mineral and plant raw materials, which were natural components in the technological process (Robinson et al. 2004; Purowski 2019).

Jan Kowalczyk returned to the issues of the Strzyżów culture and the transition from the Neolithic to the Bronze Age in later publications as a sideline on his Neolithic studies, at the same time repeating the call for intensification of research on that period (Kowalczyk 1961: 36; 1963a: 74; 1968; 1971; 1976: 18I-182; 1977). In particular, it is worth mentioning the article titled: $Z$ zagadnien kultury ceramiki sznurowej [The issues of Corded Ware culture] published in the book: Liber Josepho Kostrzewski octogenario a veneratoribus dicatus (Kowalczyk 1968). There he raises, among other things, the question of the specificity of the ceramic products in the Strzyżów culture and at the same time, noticed the similarity of this culture's flint-working to that of the other groups of that time (Kowalczyk 1968: I2O-I2I). The correctness of these observations is proved by the first analytical studies on Early Bronze Age flint production, published about twenty years later (e.g. Kopacz and Valde-Nowak 1987; Budziszewski 199i). He also wrote about the genesis of the Strzyżów culture, which - in his opinion - is a fairly clear example of migration from the north (Kowalczyk 1968: I2I). According to J. Kowalczyk, this was indicated by the technique of surface treatment of the vessels, for which he saw analogies in the forest zone. This hypothesis, however, did not find adherents in later times. It was not supported by the material evidence or developed in subsequent monographic studies.

Since the publication of the above-mentioned works by Jan Kowalczyk, in which he appealed for an intensification of research on the beginnings of the Bronze Age, views on these issues have changed radically (see Kadrow 2000; Machnik 2000). This 
I80 $\mid$ Halina Taras

is mainly due to the increase in the source data, also for the Lublin region (Machnik et al. 2009; Bargieł et al. 20I2), closest to the interests of this researcher. The issues of taxonomy and chronology of the early phase of the Bronze Age were successively studied and published, mainly by Jan Machnik. The first works, which redefine the nature of the turn of the Neolithic and Bronze Age in the areas of south-eastern Poland, were published in the 1960s (Machnik 1960; 1963; 1967). The new approach proposed by this researcher, reflecting the evolution of the Corded Ware culture, was related to the separation of - on the one hand - the Chłopice-Veselé group/culture ${ }^{\mathrm{I}}$, and - on the other - the Circum-Carpathian Epi-Corded Cultural Circle (Machnik 1967) as part of the Central European Early Bronze Age civilisation. Jan Machnik established this opinion in the 1970s (Machnik 1972; 1977; 1978).

In the last 25 years, the research on the beginnings of the Bronze Age in the Polish lands has been experiencing a tremendous growth. This also applies to the areas of southern Poland, where communities of Epi-Corded cultures functioned. The issues were studied further by J. Machnik, but were also examined by other archaeologists, including Sławomir Kadrow (Kadrow 1994; 1995) and lately Paweł Madej (2016; 2017). A summary of the state of research on the Mierzanowice culture, including the state of the source basis in the mid-I99os, is the book entitled: Kultura mierzanowicka. Chronologia, taksonomia i rozwój przestrzenny [Mierzanowice culture. Chronology, taxonomy and spatial development] (Kadrow and Machnik 1997).

At the same time, republishing of the material from old excavations and recent studies on the Strzyżów culture settlements and cemeteries, as well as the possibility of obtaining a series of radiocarbon dates, allowed for its more precise dating within the Early Bronze Age (e.g. Ślusarski and Ślusarska-Polańska 1988; Banasiewicz 1990; Bargieł 2006; Hyrchała 2005a; 2005b; Włodarczak 2017).

The intensification of field studies, especially extensive excavation work in advance of large road developments, has led in the present century to constant corrections in the picture of the Neolithic and the beginnings of the Bronze Age in the Polish lands. This picture has already been presented by the latest synthetic publications (Włodarczak ed. 2017; Bugaj ed. 2017). However, the full analysis of these valuable source data has not been completed yet, and subsequent publications - which appear every year (e.g. in the series Via Archaeologica Ressoviensia) - will probably soon result in the need for further verification.

Translated by Tomasz Myśliwiec

I This idea found the acceptance of J. Kowalczyk (Kowalczyk 1963b). Machnik himself later withdrew this idea (Machnikowie and Kaczanowski 1987: I03-107, Machnik 1989). 


\section{REFERENCES}

Banasiewicz, E. 1990. Badania na cmentarzysku kultury strzyżowskiej w Hrubieszowie Podgórzu, woj. Zamość, w latach 1983-1986. Sprawozdania Archeologiczne 42: 213-226.

Bargieł, B. 2006. Kultura strzyżowska w świetle znalezisk grobowych. Wiadomości Archeologiczne 58: 65-99.

Bargieł, B., Libera, J., Nogaj-Chachaj, J. and Zakościelna, A. 20I2. Stan badań nad epoką kamienia i wczesną epoką żelaza na Lubelszczyźnie w 50 lat po wydaniu "Materiałów do badań ..." Stefana Noska. In A. Zakościelna (ed.), Miejsce Profesora Stefana Noska w archeologii polskiej. so lat po wydaniu "Materiatów do badań nad historia starożytna i wczesnośredniowieczna międzyrzecza Wisty i Bugu", 69-Ioo. Lublin.

Bąbel, J. I978. Groby neolityczne ze stan. I w Mierzanowicach, woj. tarnobrzeskie. Wiadomości Archeologiczne 44: 67-86.

Bąbel, J. 2013. Cmentarzyska spoteczności kultury mierzanowickiej na Wyżynie Sandomierskiej. T. I i 2. Rzeszów.

Budziszewski, J. 1991. Krzemieniarstwo ludności Wyżyny Środkowopolskiej we wczesnej epoce brązu. In J. Gurba (ed.), Schytek neolitu i wczesna epoka brązu w Polsce środkowowschodniej (materiaty z konferencji), 18I-208. Lublin. Lubelskie Materiały Archeologiczne 6.

Bugaj, U. (ed.) 2017. Polish lands from the first evidence of human presence to the Early Middle Ages. Warszawa. Past Societies. T. 3-2000-500 BC.

Clark, J. G. D. 1957. Europa przedhistoryczna. Warszawa.

Gardawski, A. 1959. Plemiona kultury trzcinieckiej w Polsce. Materiaty Starożytne 5: 7-189.

Głosik, J. 1958a. Groby kultury ceramiki sznurowej w miejscowości Gródek Nadbużny, pow. Hrubieszów. Wiadomości Archeologiczne 25: 160-164.

Głosik, J. 1958b. Nowy grób kultury ceramiki sznurowej w Gródku Nadbużnym, pow. Hrubieszów. Wiadomości Archeologiczne 25: 382-384.

Głosik, J. 1968. Kultura strzyżowska. Materiaty Starożytne II: 7-II4

Hyrchała, A. 20I5a. Kultura strzyżowska - początek nowej epoki. In A. Hyrchała and B. Bartecki (eds), Wojownik i księżniczka. Archeologia - medycyna sądowa-sztuka, 32-5I. Hrubieszów.

Hyrchała, A. 20I5b. Wojownik i księżniczka z Rogalina - nowy rozdział w dziejach badań nad kulturą strzyżowską. In A. Hyrchała and B. Bartecki (eds), Wojownik i księżniczka. Archeologia-medycyna sądowa-sztuka, 52-79. Hrubieszów.

Kadrow, S. 1994. Social structures and social evolution among Early-Bronze-Age communities in South-Eastern Poland. Journal of European Archaeology 2(2): 229-248.

Kadrow, S. 1995. Gospodarka i spoteczeństwo. Wczesny okres epoki brazu w Matopolsce. Kraków.

Kadrow, S. 2000. Badania nad wczesnym okresem epoki brązu. In M. Kobusiewicz and S. Kurnatowski (eds), Archeologia i prahistoria w ostatnim pótwieczu, I33-I38. Poznań.

Kadrow, S. and Machnik, J. 1997. Kultura mierzanowicka. Chronologia, taksonomia i rozwój przestrzenny. Kraków.

Kopacz, J. and Valde-Nowak, P. 1987. Episznurowy przykarpacki krąg kulturowy w świetle materiałów kamiennych. Archeologia Polski 32: 55-92.

Kostrzewski, J. 1939-1948. Od mezolitu do okresu wędrówek ludów. In S. Krukowski, J. Kostrzewski and R. Jakimowicz (eds), Prehistoria ziem polskich, II8-36I, tabl. 50-90. Kraków. Encyklopedia Polska PAU, t. IV, część I.

Kostrzewski, J. I949. Pradzieje Polski. Poznań.

Kowalczyk, J. 1957. Sprawozdanie z badań osady kultury pucharów lejkowatych w Gródku Nadbużnym, pow. Hrubieszów, w 1956 r. Wiadomości Archeologiczne 24: 300-306. 
I82 $\mid$ Halina Taras

Kowalczyk, J. 1959. Zagadnienie kultury mierzanowickiej zwanej także tomaszowską. Wiadomości Archeologiczne 27: I-7.

Kowalczyk, J. 1961. Postulaty badawcze neolitu polskiego. Sprawozdania z posiedzeń Komisji Naukowych Oddziatu PAN w Krakowie, 35-37.

Kowalczyk, J. I963a. Niektóre problemy polskiego neolitu w świetle nowszych badań. Prace i Materiaty Muzeum Archeologicznego i Etnograficznego w Eodzi. Seria Archeologiczna 10: 65-75.

Kowalczyk, J. 1963b. Terminologiczne konsekwencje. Wiadomości Archeologiczne 29: I-8.

Kowalczyk, J. 1968. Z zagadnień kultury ceramiki sznurowej. In K. Jażdżewski (ed.), Liber Josepho Kostrzewski octogenario a veneratoribus dicatus, II7-I23. Wrocław.

Kowalczyk, J. 1971. Zmierzch epoki kamienia. Wrocław.

Kowalczyk, J. 1976. Die Gliederungsprobleme des polnischen Neolithikums. Archaeologia Polona I7: I77-I83.

Kowalczyk, J. 1977. Das Spätneolithikum der VR Polen und seine Beziehungen zum Süden der Deutschen Demokratischen Republik. Arbeit und Forschungsberichte zu sächsische Bodendenkmalplege 22: 219-223. Dresden.

Kozłowski, L. 1928. Wczesna, starsza i środkowa epoka brązu $w$ Polsce $w$ świetle subborealnego optimum klimatycznego i jego wptywu na ruchy etniczne i zaludnienie Polski. Lwów.

Libera, J. 200I. Krzemienne formy bifacjalne na terenach Polski i zachodniej Ukrainy (od środkowego neolitu do wczesnej epoki żelaza). Lublin.

Machnik, J. I960. Ze studiów nad kulturą ceramiki sznurowej w Karpatach polskich. Acta Archaeologica Carpathica 22: 55-86.

Machnik, J. 1963. Uwagi o związkach i chronologii niektórych znalezisk kultury ceramiki sznurowej w Karpatach. Acta Archaeologica Carpathica 4: 9I-I07.

Machnik, J. 1966. Studia nad kulturą ceramiki sznurowej w Matopolsce. Wrocław.

Machnik, J. 1967. Stosunki kulturowe na przełomie neolitu i epoki brązu w Małopolsce (na tle przemian w Europie Środkowej). In W. Hensel (ed.), Materiaty do prahistorii ziem polskich. Część 3: Epoka brązu, z. I. Warszawa.

Machnik, J. 1972. Die Mierzanowice-Košt’any-Kultur. Slovenská Archelógia 20: 177-188.

Machnik, J. 1977. Frühbronzezeit Polens (Übersicht über die Kulturen und Kulturgruppen). Wrocław.

Machnik, J. 1978. Wczesny okres epoki brazu. In A. Gardawski and J. Kowalczyk (eds), Wczesna epoka brązu, 9-I36. Wrocław. Prahistoria ziem polskich. T. III.

Machnik, J. 1989. Neue Angaben für die Periodisierung der Frühbronzezeit in Kleinpolen. Praehistorica I5: 275-279.

Machnik, J. 200o. Badania nad przełomem neolitu i epoki brązu. In M. Kobusiewicz and S. Kurnatowski (eds), Archeologia i prahistoria w ostatnim pótwieczu, I09-I26. Poznań.

Machnik, J., Bagińska, J. and Koman, W. 2009. Neolityczne kurhany na Grzędzie Sokalskiej w świetle badań archeologicznych w latach 1988-2006. Kraków.

Machnikowie, A. and J. and Kaczanowski, K. 1987. Osada i cmentarzysko z wczesnego z wczesnego okresu epoki brazu na "Górze Klin" w Iwanowicach. Wrocław.

Madej, P. 20I6. Kultura mierzanowicka w karpackiej częśi dorzecza Wisty. Unpublished PhD thesis, Jagiellonian University of Kraków.

Madej, P. 2017. Dwa nurty rozwoju kultury mierzanowickiej w Karpatach polskich i na ich północnym przedpolu. In J. Gancarski (ed.), Stan i potrzeby badań archeologicznych w Karpatach, 315-323. Krosno.

Nosek, S. 1957. Materiały do badań nad historia starożytną i wczesnośredniowieczną międzyrzecza Wisły i Bugu. Annales Universitatis Mariae Curie-Sktodowska, sec. F/ VI (I95I).

Podkowińska, Z. 1936. Wykopaliska w Strzyżowie, przeprowadzone w 1935 r. Z otchtani wieków II: 72-77. 
Purowski, T. 2019. Od fajansu do szkta. Kontakty ziem polskich z gtównymi centrami cywilizacyjnymi w II-I tys. p.n.e. w świetle badan archeometrycznych tworzyw szklistych. Warszawa.

Robinson, Ch., Baczyńska, B. and Polańska, M. 2004. The Origins of Faience in Poland. Sprawozdania Archeologiczne 56: 79-154.

Salewicz K. 1937. Tymczasowe wyniki badań prehistorycznych w Mierzanowicach. Z otchtani wieków I2: $39-59$.

Ślusarski, Z. and Ślusarska-Polańska, M. 1988. Badania stanowisk kultury strzyżowskiej w RaciborowicachKolonii, woj. Chełm, w latach 1956, 1958 i 1959. Sprawozdania Archeologiczne 40: 167-196.

Włodarczak, P. 2006. Kultura ceramiki sznurowej na Wyżnie Matopolskiej. Kraków.

Włodarczak, P. 20I7. Małopolska at the beginning of the Bronze Age (2000-160o BC). In U. Bugaj (ed.), Polish lands from the first evidence of human presence to the Early Middle Ages, 49-85. Warszawa. Past Societies. T. 3-2000-500 BC.

Włodarczak, P. (ed.) 2017. Polish lands from the first evidence of human presence to the Early Middle Ages. Warszawa. Past Societies. T. $2-5500-2000$ BC. 
